\title{
An Analysis of Minimum Service Standards (MSS) in Basic Education: A Case Study at Magelang Municipality, Central Java, Indonesia
}

\author{
Sri Haryati ${ }^{1}$ \\ ${ }^{1}$ Tidar University of Magelang, Central Java, Indonesia \\ Correspondence: Sri Haryati, Faculty of Education, Tidar University of Magelang, Central Java, Indonesia. Tel: \\ 62-813-2587-7915. E-mail: sriharyati717@yahoo.com
}

Received: May 12, 2014 Accepted: June 16, 2014 Online Published: September 23, 2014

doi:10.5539/ies.v7n10p32

URL: http://dx.doi.org/10.5539/ies.v7n10p32

\begin{abstract}
The study aims at analyzing the achievement of Minimum Service Standards (MSS) in Basic Education through a case study at Magelang Municipality. The findings shall be used as a starting point to predict the needs to meet MMS by 2015 and to provide strategies for achievement. Both primary and secondary data were used in the study investigating the gap between the real achievements and the standards as set out in MMS in terms of the number of schools and classrooms, support facilities, teachers, education staff, including books and teaching media. A little bit of non-personnel budgeting was also observed to be matched with the standards as set out by Education Ministry No. 69/2009. It turned out that classrooms and teachers outnumbered in Magelang with reference to the distribution of students and teachers according to national MMS even seemingly a waste of money. Teachers were abundant 2010 and would remain as such in 2015. Classrooms for Elementary Schools would be sufficient up to 2015, and six additional classrooms would be needed for Junior High Schools. However teachers' qualifications were far from fulfilling MMS including the school principals. There lacked support facilities including books and teaching media. Meanwhile non-personnel budgets were low including allocation of funds for school supplies. Therefore, it is high time that City Government prioritized 9-year-obligatory education by redistribution of students and teachers, improvement of teachers' qualifications, upgrade of school facilities in accordance with MMS and improved efficiency of school budgets.
\end{abstract}

Keywords: basic education, minimum service standards, teachers' qualifications, school facilities

\section{Introduction}

The Government of the Republic of Indonesia has stipulated the implementation of 9-year obligatory education under Law No. 20 / 2003 and further specified in Government Regulations No. 47 / 2008 in which central and local governments shall provide the basic education (6-year elementary school (SD) and 3-year junior high school (SMP)) free of charge for children aged 7 to 12. It is also a manifestation of Indonesian Constitution 1945 as stipulated in Article 31 that each citizen has the right for education. For this purpose, the local government has launched BOS (School Operational Fund) program to be given to state-owned SD and SMP throughout Indonesia in support of education for free or at least for lower school fees. The problem is whether or not such a program has touched the poor. Often times (Fitrie, 2013) the poor was victimized by the school management by the presence of the School Committee which seems not to support the poor in the sense that they collect money from the community as they wish, claiming that there has been a unanimous decision over how much each student shall pay for admission. At present, there are of course few state schools which rely heavily on BOS and thus require no payment from the students. The funds are managed in such a way to make both ends meet. This has, however, resulted in poor quality education.

\subsection{Decentralized Basic Education (DBE)}

DBE aims at providing education in accordance with the school capacity since there are varieties of schools in terms of location, facilities, and human resources. Thus, each school is given freedom of management. There is a wide gap between school for the poor and that for the rich, resulting in poor and good quality education. Still another problem is that some of the school management are craving for money and ignorant of the community's monetary crisis. In other words, free education remains a dream; there is always fund raising for one cause or another. Haryati (2014) concluded that fully-accredited schools did not always comply with the standards set by the school accreditation board. Similar studies (Herwin, 2012; Yulmarses, 2011) reported an academic research 
(thesis) on the education at Sangir sub-district Solok Selatan district and Pariaman Municipality that the gap between the reality and the criteria set up in MSS reflected in poor education services. The current study differs in the setting, that is in Magelang municipality where the researcher is a lecture at Tidar University Magelang to see whether the results support or deny the previous studies.

Accreditation is not the same as MSS since the former refers to school-based achievement of certain criteria set by the accreditation board while the later refers to regional achievement contributed by a group of schools. The later uses certain criteria set out by the government on or above which the schools in a certain region have met determined quality standards of acceptance. The current study therefore investigated the reality of standard achievement against MSS to identify if there is a gap between the two in order to further formulate strategic plan to narrow or even eliminate the gap.

The issues dealt with in the study include the number of schools and classrooms in one region, support facilities, teachers and academic staff, books and teaching media in addition to non-personnel budgeting in the hope that a clear representation of education in Magelang can be obtained in order to be able to offer strategies for minimum standard achievement.

\subsection{Minimum Service Standards (MSS)}

MSS are assigned as benchmarks of minimal fulfillment of school operation and implemented under Government Regulation No. 19/2010. These are the minimum requirement standards for schools throughout Indonesia used as a basis of planning, implementation and supervision in support of quality education at national level for civilized and educated Indonesian citizens. Table 1 below shows the indicators of MSS of education:

Table 1. Indicators of minimum service standards

\begin{tabular}{|c|c|c|c|}
\hline \multirow[t]{2}{*}{ No. } & \multirow[t]{2}{*}{ Indicators for MSS } & \multicolumn{2}{|l|}{ Minimum Standards } \\
\hline & & Elementary School & Junior High School \\
\hline 1. & Walking distance from remote areas & $3 \mathrm{kms}$ & $6 \mathrm{kms}$ \\
\hline 2. & Ratio of students per class (R-S/C max) & 32 & 36 \\
\hline 3. & Teachers' rooms / school & 1 & 1 \\
\hline 4. & Principal's room / school & - & 1 \\
\hline 5. & Physics Lab & & Capacity of 36 students \\
\hline 6. & Availability of teachers & $\begin{array}{l}\mathrm{R}-\mathrm{S} / \mathrm{T} \max =32 \\
\text { Each unit of edu, } 6 \\
\text { teachers, for special } \\
\text { region, } 4 \text { teachers }\end{array}$ & $\begin{array}{l}1 \text { teacher for } 1 \text { subject and } \\
\text { in special case, } 1 \text { teacher for } \\
1 \text { field of study }\end{array}$ \\
\hline 7. & Teachers' qualifications & $\begin{array}{l}\text { Each school } \\
2 \text { undergraduates } \\
2 \text { certified }\end{array}$ & $\begin{array}{l}70 \% \text { of undergrad; } 30 \% \\
\text { certified for a special region } \\
40 \% \text { and } 20 \% \\
\text { Undergrad \& certified for } \\
\text { Math } \\
\text { Physics } \\
\text { Indonsian } \\
\text { English }\end{array}$ \\
\hline 8. & Principal's qualifications & Undergrad + certification & \\
\hline 9. & School supervisor's qualifications & Undergrad + certification & \\
\hline 10. & Textbooks & $\begin{array}{l}1 \text { set/student for subjects } \\
\text { Indonesian language } \\
\text { Mathematics } \\
\text { Physics }\end{array}$ & \\
\hline
\end{tabular}




\section{Social Science}

11. Physics teaching media

12. Enrichment and reference books

13. Teachers' work hours per week

14. Class sessions per week
1 set consisting of

Skeleton model

Human body model

Physics kits

Physics posters

100 enrichment textbook

10 reference books

37.5

200 enrichment textbooks

20 reference text books

37.5

Class I-II $=18$ hours

Class III $=24$ hours

Class IV-VI=27 hours

School unit based
School unit based

15. Curriculum

It should be noted that basic education is vital in preparation of capable human resources. At this level, students are equipped with basic knowledge for further development. Elfindri (2008, pp. 227-228) stated that basic education is the target of MDGs (Millennium Development Goals) of 2015 and the struggle of EFA (Education for All) and to which the government is fully committed (Bappenas, 2010, p. 1). With respect to non-personnel budget, it is stipulated under Government Regulations No. 69/2009 in which it is assumed that Elementary school has 6 learners' groups, each consisting of 28 students and Junior High School has 6 learners groups consisting of 32 students. The current study replicated Herwin's Analisis Pencapaian Standar Pelayanan Minimal (SPM) Pendidikan Dasar, Studi Kasus Kecamatan Sangir Kabupaten Solok Selatan (2012) which was a possible replica of Yulmarses' (2011) Analisis Pencapaian Standar Pelayanan Minimum Pendidikan Dasar Sembilan Tahun di Kota pariaman, another replica of Verra's (2007) Analisis Pencapaian Standar Pelayanan Minimum Pendidikan Dasar Sembilan Tahun di Kabiupaten Padang pariaman. They primarily differed in the research settings. The current study was conducted in Magelang Municipality, Central Java, Indonesia.

\section{Method}

The current study was conducted in Magelang municipality employing both primary and secondary data. The secondary data were taken from related offices, such as books of education profiles, education offices' strategic plas, and budgets of both short-term and long-term. Meanwhile, the primary data were gathered through administration of questionnaires to randomly selected principals. In addition, interviews were conducted to collect data from Head of Bappeda (Regional Development), Head of Education Office, Head of Education Program Division.

Gap analysis was performed in order to know to what extent the reality (standards achieved) differs from the standards set out in MSS for each school under study-20 schools (15 Elementary and 5 Junior High Schools) randomly sampled out from Magelang Municipality - on the basis of which the needs for infrastructure and budget can be predicted for better achievement of MSS in 2015.

\section{Results}

The gap analysis showed that as of 2013 Magelang municipality had not fully implemented MSS program as outlined below:

\subsection{Walking Distance}

A number of schools in Magelang municipality have offered 9-year obligatory education with factual participation indexes (FPI) of 94\% for Elementary Schools and 89\% for Junior High Schools, implying that it was somehow hard to get access to quality education. In 100 children of 0.6-12 years old, only 89 managed to go to Elementary Schools; and the other six did not. Similarly, 89 children of 12-15 years of age managed to go to Junior High Schools but not the other 11 children. The primary problem was assumed to be of finance. In addition, there were students who still had to walk for more than three kilometers from their houses to schools at some remote areas. 


\subsection{Ratio of Students per Class $(R-S / C)$}

The ratio of students per class (R-S/C) for Elementary Schools was of 28.51 and Junior High Schools of 26.84 . With the present total of groups of learners, there got lack of classrooms in both Elementary and Junior High Schools. This was caused by unequal distributions of students at schools in Magelang, resulting in various R-S/C for each school. Had the student distributions been re-arranged according to MSS of basic education along with the restoration of the dysfunction buildings, there would have been abundant classrooms of 36 for Elementary Schools and 19 for Junior High Schools.

\subsection{The Total Number of Teachers}

There were already abundant teachers in Magelang municipality. In 2013 with the current number of groups of learners, the surplus of teachers in Elementary Schools reached 14 classroom teachers, 15 religion teachers and 2 physical education (sport) teachers. If the students had been redistributed in accordance with MSS, the surplus of teachers would have been 77 teachers. Meanwhile, Junior High Schools had surplus of teachers. If the teaching hours had been maximized by letting teachers to teach in other schools to get 24 hours of teaching per week, the surplus would have been 94 teachers.

\subsection{Teachers' Qualifications}

When calculated on the basis of MSS by percentage, there were sufficient teachers with undergraduate degrees for Junior High Schools. However, for particular subjects which must be taught by teachers with undergraduate degrees, Junior High Schools lacked two mathematics teachers, three physics teachers, two Indonesian language teachers and two English teachers. Meanwhile, Elementary Schools lacked 20 teachers to comply with MSS for basic education.

For the obligation to have certified teachers at Elementary Schools, there lacked 55 teachers to comply with MSS. For Junior High Schools, there lacked 22 certified teachers as required by MSS. Meanwhile, for certain subjects which have to be taught by certified teachers, there lacked seven mathematics teachers, seven physics teachers, seven Indonesian language teachers, and seven English teachers.

\subsection{Principals' Qualifications}

Junior High Schools managed to fulfill the minimum requirement of having principals with undergraduate degrees. Meanwhile in Elementary Schools, there were 11 principals without undergraduate degrees out of 32 principals. Meanwhile certified principals were rare individuals. There were 22 Elementary Schools and 2 Junior High Schools whose principals have not been certified.

\subsection{Supervisors' Qualifications}

Supervisors' qualifications of undergraduate had been fulfilled in both Elementary and Junior High Schools. Meanwhile the obligation to have certified supervisors had also been fulfilled despite the fact that there was one Elementary School supervisor who was not certified yet.

\subsection{Availability of Textbooks}

Both Elementary and Junior High Schools had not yet met the obligation to provide textbooks covering the number of students; particular subjects in Elementary Schools and all subjects in Junior High Schools. There were however six Elementary Schools which had fulfilled MSS.

\subsection{Availability of Enrichment and Reference Textbooks}

Both Elementary and Junior High Schools had not yet fulfilled MSS with respect to the availability of enrichment and reference textbooks. The last but of no least importance is that the obligation to provide teaching media had been $79 \%$ fulfilled.

\subsection{Budget Analysis}

The allocation of non-personnel operational funds in a unit of school is stipulated under Education Ministerial Regulations No. 69 /2009. In Magelang by average, the non-personnel budget for Elementary Schools was of $77.78 \%$ out of the standard and for Junior High Schools of 74.03\% of the standard. The Allocation of funds for school supplies was appropriate or even tended to be a waste of money at Elementary Schools and Junior High Schools approaching the standard. Meanwhile, the allocation of funds for consumable materials was minimized.

\subsection{Analysis of Projected Achievements of MSS Basic Education and MDGs in 2015}

The number of population can be predicted, so can the number of students in Elementary and Junior High Schools up to 2015 with the use of Square Multiplier. With reference to MDGs, it is predicted that the factual 
participation index (FPI) will be $100 \%$ in 2015 .

Pertinent to the composition of students based on ages in 2010, Rough Participation Index (RPI)up to 2015 can be predicted, assuming FPI of $100 \%$ as presented in Table 2 below:

Table 2. The projected number of elementary and junior high school students in Magelang in 2015

\begin{tabular}{|c|c|c|c|c|c|c|}
\hline Year & 2010 & 2011 & 2012 & 2013 & 2014 & 2015 \\
\hline RPI $(\%)$ of ES & 111.45 & 111.95 & 112.45 & 112.95 & 113.45 & 113.95 \\
\hline RPI (\%) of JHS & 85.45 & 93.12 & 100.78 & 108.45 & 116.12 & 123.78 \\
\hline$\sum$ of ES Students & 15,225 & 15,380 & 15,580 & 15,835 & 16,135 & 16,490 \\
\hline$\sum$ of JHS Students & 8,477 & 8,632 & 8,832 & 9,087 & 9,387 & 9,742 \\
\hline
\end{tabular}

Note: the 2012 baseline was taken from Magelang City Council.

The number of Students in 2015 can be used as the basis to predict the needs for classrooms for each level in Magelang. Meanwhile the MSS require that each classroom be occupied by 32 Elementary School Students (ESS), and 36 Junior High School Students (JHSS). It turns out that up to 2015 the classrooms are sufficient for ESS despite the fact that the available rooms shall be repaired or restored.

As for JHSS, there are sufficient classrooms up to 2014. An addition of 6 classrooms is predicted in 2015. The teachers' and principals' rooms shall be added to fulfill the MSS. Physics Labs shall also be completed as they are important in the learning process.

Upon careful calculation, actually there are abundant teachers in 2015 in comparison with the condition in 2010. The problem is that more teachers are available but there lack teachers with qualifications as set out in MSS. In Elementary Schools, for example, there lack 22 teachers with undergraduate degrees and 57 certified teachers to meet the requirements of MSS. Due to fact that there are no more additional (newly-established) schools, the number of teachers required remains the same in 2015.

Meanwhile, for Junior High Schools, there lack 22 teachers with certification if the teachers are redistributed in line with MSS, namely $35 \%$ of the total teachers per school. With respect to the availability of certified teachers, if they are redistributed, there lack 31 certified teachers. MSS have been fulfilled in terms of teachers with undergraduate degrees.

On the demand for the availability of textbooks, enrichment books and reference books, the number remains the same as set out in MSS. However, it is necessary to complete the reference books in addition to the teaching media. The number remains the same.

With respect to budgeting, prediction can be made up to 2015 as can be seen in Table 3 below:

Table 3. Prediction on the government budget for the 9-Year obligatory education

\begin{tabular}{ccccccc}
\hline Year & $\begin{array}{c}2010 \\
(\text { IDR })\end{array}$ & $\begin{array}{c}2011 \\
(\text { IDR })\end{array}$ & $\begin{array}{c}2012 \\
(\text { IDR })\end{array}$ & $\begin{array}{c}2013 \\
(\text { IDR })\end{array}$ & $\begin{array}{c}2014 \\
(\text { IDR })\end{array}$ & $\begin{array}{c}2015 \\
(\text { IDR })\end{array}$ \\
\hline $\begin{array}{c}\text { Elementary School } \\
\text { Budget }\end{array}$ & $6,125,412,300$ & $6,279,901,296$ & $6,479,201,398$ & $6,728,392,882$ & $7,033,765,320$ & $7,398302,856$ \\
$\begin{array}{c}\text { Junior High School } \\
\text { Budget } \\
\text { Total }\end{array}$ & $3,065,991,435$ & $3,296,881,633$ & $3,539,927,492$ & $3,804,389,946$ & $4,090,560,517$ & $4,408,382,460$ \\
& $9,191,403,735$ & $9,576,782,929$ & $10,019,128,890$ & $10,532,782,827$ & $11,124,325,839$ & $11,806,685,316$ \\
\hline
\end{tabular}

Source: Herwin (2012, p. 20).

The above figures shall refer to the total amount of money known as BOS (School Operational Grant). A school may heavily rely on this grant for the overall educational operation. Another school may also want to ask for additional funds from the students under the management of School Committee. Due to the various types of school managements, therefore the government needs to provide MSS (Minimum Service Standards) in order for 
all the schools to perform educational operation following certain rules of conducts.

\section{Discussion}

The current study has outlined the problems in the implementation of MSS. There are basically 15 items to be fulfilled by each school in order to perform minimum services to the public. It can therefore be said that MSS is the lowest border line of quality below which a school may be categorized as a low quality education provider. A better school is, of course, the one which can go beyond MSS.

With respect to the relevance of the study to Herwin's (2012), the year in which MSS program just started, the current study supports Herwin's in the sense that fulfilling the requirements as set by MMS is somehow hard especially for the schools located in remote areas where access to technology and source of funds are really limited. This has resulted in the diversity in quality education. An extreme case may be taken as an example here. Some schools have complete facilities and infrastructure, certified teachers, complete textbooks, reference books, and conducive learning environments. Some other schools may have everything limited to educational elements as required by MSS. Still some others have found it extremely difficult to comply with MSS, and yet they still have to perform educational services to help students who may not be able to get access to the favorite schools due to one thing or another, mostly financial problems.

Despite the fact that there are various types of schools in terms of services - whether they are below or beyond MSS, all students must do the same national examination with a particular exception of Elementary Schools which have stopped doing the national examination in 2013. Therefore it goes without saying that the national examination has become a frightening issue especially for students at the remote areas where MSS have not been fulfilled.

At the other side, the Government of Indonesia, through the Department of Education and Culture provide grants known as BOS (Bantuan Operasional Sekolah or School Operational Grants) in support of the spirit of Free Education. Unfortunately, only some schools manage to offer free education based on BOS with everything so limited - and probably resulting in low quality education. Some other schools moderately ask for school fees to cover the needs for more complete facilities.

\section{Direction of Policies}

Presented below are similar strategies as offered by Herwin (2012) with some additional issues to overcome the current problems of education in response to the results of the current study.

- $\quad$ Equal access to education services through:

- Distribution of students should be made in accordance with the regulation of new student intake capacity. Thus cooperation among schools should also be made in such a way that no school has the ratio of students per class (R-S/C) of more than 32 students for Elementary School and 36 students for Junior High School. It is possible because transportation is not a problem. Parents may their children to school on motorbikes. In addition, students may be made access to bicycles of their own or the schools'.

- It is also a good idea to build a boarding house for students who live far from schools more than as set by MSS.

- Distant classrooms may also be set up for those who cannot be handled using strategy as above.

- $\quad$ Providing and upgrading good quality educational infrastructure.

This applies to both Elementary and Junior High Schools in order for them to minimally comply with MSS.

- $\quad$ Regulating the distribution of improved quality of teachers and educational staff.

This is important not to place abundant certified and qualified teachers in one schools while another lacks.

- Increasing participation index of the community in basic education.

It is important to note that in 2015 the factual participation index of basic education must reach $100 \%$ as planned in the MSS program.

- $\quad$ Managing educational budget.

This applies to schools which rely heavily on grants (BOS) and those which still receive school fees. The funds should be appropriately allocated on a priority basis.

- Cyber and computer literacy should be introduced at earlier age to gain the best impact of information technology. 


\section{Recommendations}

Based on the findings of the current study, the following issues are recommended for improvement and betterment of education in Magelang municipality and probably elsewhere throughout Indonesia since the current study supports the previous studies (Herwin 2012; Haryati, 2014).

- Local governments should provide financial grants to schools which lack infrastructure and support facilities, such as teachers' rooms, principals' rooms and physics labs.

- No more recruitment of teachers; what is important at the moment is the upgrade of teachers. Even, if at all possible, teachers may be relocate elsewhere in order to have maximal working hours as set by National Standards of Education and Minimum Service Standards in addition to maximizing teachers to get at least undergraduate degrees

- Textbooks are urgent to guarantee sustainable quality education. Therefore, it is a must to equip the students with complete textbooks and references. Internet access can be made possible, especially for Junior High School Students as they may want to read e-books and get access to other necessary information.

- For the 9-year obligatory education to succeed, it is important to reconsider increasing the educational budget more than $20 \%$ as it is stipulated. In addition, some posts for non-personnel budgets should be created in order to improve the quality of performance.

- MSS should be integrated in the education strategic plans so that the minimal services can be offered to all stakeholders.

- As dynamic changes in prices occur on a regular basis, the government should also consider increasing some items with higher budgets in order for the schools not to raise funds from the students' parents.

\section{Acknowledgements}

The writer's sincere thanks and gratitude shall go to Prof. Dr. Sukarno, M.Si for his sponsorship; the principals of selected schools who have participated in the study as the subjects, the officials at Bappeda, Education Office, Magelang City Council for their participation in the interviews; many more individuals whose names the writer cannot mention one by one but who have contributed directly or indirectly to the completion of the study.

\section{References}

Bappenas. (2007). Laporan Perkembangan Pencapaian Millennium Development Goals Indonesia 2007. Jakarta: Bappenas.

Bappenas. (2010). Lampiran Peraturan Presiden Nomer 5 Tahun 2010 tentang Rencana Pembangunan Jangka Menengah Nasional (RPJMN) 2010-2014. Jakarta: Bappenas.

Bappenas. (2010). Laporan Pencapaian Tujuan Pembangunan Millennium di Indonesia 2010. Jakarta: Bappenas.

Daroesman, R. (1975). Pembiyaan Pendidikan di Indonesia. Jakarta: PT. Badan Penerbit "Indonesia Raya".

Elfindri. (2008). Strategi Sukses Membangun Daerah. Jakarta: Gorga Media.

Haryati, S. (2014). 'An Evaluative Review of School Accreditation Implementation Program in Indonesian Contexts' in International Education Studies. Open Access Journal, 7(5), 138-146. Retrieved from http://www.ccsenet.org/journal/index.php/ies/article/view/33964/20534

Herwin. (2012). Analisis Pencapaian Standar Pelayanan Miminal (SPM) Pendidikan Dasar, Studi Kasus: Kecamatan Sangir Kabupaten Solok Selatan. Unpublished Summary of a Thesis. Andalas: Program Pasca Sarjana, Universitas Andalas.

Kementrian Pendidikan Nasional. (2010). Rencana Strategis Kementrian Pendidikan Nasional 2010-2014. Jakarta: Kemendiknas.

Nasution. (2003). Metode Research (Penelitian Ilmiah) Edisi Keenam. Bandung: Bumi Aksara.

Verra, S. (2007). Analisis Pencapaian Standar Pelayanan Minimum Pendidikan Dasar Sembilan Tahun di Kabupaten Padang Pariaman (Unpublished Thesis). Andalas: Program Pascasarjana Universitas Andalas.

Yulmarses, A. (2011). Analisis Pencapaian Standar Pelayanan Minimum Pendidikan Dasar Sembilan Tahun di Kota Pariaman (Unpublished thesis). Andalas: Program Pascasarjana Universitas Andalas. 


\section{Copyrights}

Copyright for this article is retained by the author(s), with first publication rights granted to the journal.

This is an open-access article distributed under the terms and conditions of the Creative Commons Attribution license (http://creativecommons.org/licenses/by/3.0/). 